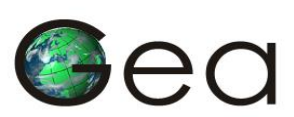

JURNAL PENDIDIKAN GEOGRAFI

\title{
PENGARUH MODEL PEMBELAJARAN LEARNING CYCLE DAN MODEL PEMBELAJARAN SEARCH, SOLVE, CREATE, AND SHARE TERHADAP PEMAHAMAN KONSEP-KONSEP GEOGRAFI
}

\author{
${ }^{1}$ Irfan Rifani, ${ }^{2}$ Darsiharjo, ${ }^{3}$ Mamat Ruhimat \\ ${ }^{1}$ SMPN 2 Cihaurbeuti Ciamis Email: faiepeucangcomet3@yahoo.co.id \\ 2Jurusan Pendidikan Geografi, FPIPS UPI, email: darsiharjo@y ahoo.com \\ ${ }^{3}$ Jurusan Pendidikan Geografi, FPIPS UPI, email: mamat_ruh@yahoo.co.id
}

\begin{abstract}
The background of this research is the lack of students abilities in concept understanding. It caused by low use of their mind in conceptual change process. Researcher tried to use the Learning Cycle model and Learning Search, Solve, Create and Share (SSCS) model to improve students understanding concept. We used pretest - post test comparison group design experiment method. We got the data by giving pretest and post test, by using students worksheet and observation. We analyzed the data byusing percentage technique and z-test. We got the result that showed: the first, using Learning Cycle and Solve, Create and Share (SSCS), the students concept understanding ability was increased. Second, most of the concept understanding indicator has been achieved by students except the ability of exemplifying. Third, there are some students that have disconcept. Fourth, the effectives of using Learning Cycle and Solve, Create and Share (SSCS) model included: the improvement of student activities support the effectives oflearning that show the $1^{\text {st }}, 2^{\text {nd }}$, and $3^{\text {rd }}$ learning process that better. Second, teachers effort give students motivations to study well. The effective and non cognitive value must be attended by teacher as an effort to teach another material learned by students. In this case, teacher has important role in teaching and learning process and in supporting the effectives of it.
\end{abstract}

Keywords: teaching learning model, learning cycle, SSCS, concept understanding.

\begin{abstract}
ABSTRAK
Penelitian ini dilatarbelakangi oleh kurangnya kemampuan pemahaman konsep pada peserta didik. Rendahnya pemahaman konsep ini disebabkan oleh penggunaan pola pikir yang rendah pada proses perubahan konseptual. Peneliti mencoba menerapkan model pembelajaran Learning Cycle dan model pembelajaran Search, Solve, Create, and Share (SSCS) untuk meningkatkan pemahaman konsep. Metode yang digunakan adalah metode eksperimen desain kelompok pembanding pretes dan postest (pretest-posttest comparasion group design).Perolehan dat a dilakukan dengan tes (pretes-postes), LKS dan pedoman observasi. Analisis data dilakukan dengan teknik persentase dan Uji z. Hasil penelitian menunjukkan: pertama, pemahaman konsep pada peserta didik dengan penerapan model pembelajaran Learning Cycle dan Search, Solve, Create, and Share (SSCS) mengalami peningkatan setelah perlakuan. Kedua, sebagian besar indikator pemahaman konsep telah dikuasai oleh peserta didik. Indikat or yang belum optimal dikuasai adalah kemampuan mencontohkan (exemplifying). Ketiga, masih terdapat pesert a didik yang mengalami miskonsepsi dan tidak menguasai konsep. Keempat, efektifitas penerapan model pembelajaran Learning Cycle dan Search, Solve, Create, and Share (SSCS) dapat disimpulkan: pertama, terjadi peningkatan aktivitas peserta didik yang mendukung efektivitas pembelajaran yang mencerminkan proses pembelajaran dari pertemuan kesatu, kedua dan ketiga mengalami perkembangan ke arah lebih baik. Kedua, guru berupanya memberi dorongan kepada peserta didik untuk selalu mengikuti pembelajaran dengan baik. Nilai afeksi dan non kognitif lainnya diperhatikan oleh guru sebagai upaya memberikan pembelajaran lain selain materi yang sedang dipelajari oleh peserta didik. Berdasarkan hal tersebut guru berperan baik dalam proses pembelajaran dan mendukung terhadap efektifit as pembelajaran yang dilakukan.
\end{abstract}

Kata kunci: model pembelajaran, learning cycle, SSCS, pemahaman konsep. 


\section{PENDAHULUAN}

Pemahaman menurut Bloom (Anderson dan Krathwohl, 2001: 67) adalah "construct meaning from instructional messages, including oral, written, and graphic communication". Pemahaman konsep diperlukan bagi peserta didik karena merupakan dasar untuk mengembangkan kemampuan berpikir. Pemahaman konsep merupakan ide kunci yang menyajikan fondasi untuk mengembangkan potensi intelektual peserta didik. Peserta didik dikatakan telah memahami konsep jika mampu menjelaskan suatu informasi dengan kata-kata sendiri dan mampu menjelaskan kembali informasi tersebut. Bloom (Anderson dan Krathwohl, 2001: 67) mengklasifikasi pemahaman sebagai kemampuan "menafsirkan (interpreting), mencontohkan (exemplifying), mengelompokkan (classifying), meringkas (summarizing), meny impulkan (inferring), membandingkan (comparing), dan menjelaskan (explaining)".

Belajar konsep berguna dalam rangka pendidikan peserta didik atau paling tidak mempunyai pengaruh tertentu. Hamalik (2001: 164) menjelaskan kegunaan mempelajari konsep sebagai berikut : 1) Konsep mengurangi kerumitan lingkungan, 2) konsep membantu untuk mengidentifikasi objek y ang ada disekitar kita, 3) konsep membantu untuk mempelajari sesuatu yang baru, lebih luas, dan lebih maju, 4) konsep mengarahkan kegiatan instrumental, 5) konsep memungkinkan pelaksanaan pengajaran, dan 6) konsep dapat digunakan untuk mempelajari dua hal yang berbeda dalam kelas yang sama.

Kenyataannya kemampuan pemahaman konsep ini masih jauh yang diharapkan. Rendahny a pemahaman konsep ini disebabkan oleh penggunaan pola pikir yang rendah pada proses perubahan konseptual. Menurut Dahar (2006: 155) perubahan konseptual melibatkan dua komponen, yaitu "kondisi yang harus dipenuhi agar terjadi perubahan konseptual dan ekologi konseptual yang meny ediakan konteks untuk berlangsungny a perubahan konseptual". Penyebab lainny a adalah pembelajaran y ang digunakan sebelumny a belum membantu peserta didik memperoleh pemahaman konsep dengan baik dan kurang menggunakan nalar logis.

Guru dituntut dapat melaksanakan kegiatan pembelajaran yang mengkonstruksi pemahaman. Upaya yang dilakukan untuk menyelesaikan kesulitan yang dialami peserta didik dalam memahami konsep, membuat proses pembelajaran menarik, tidak berupahapalan tetapi mengkonstruksi pemahaman konsep mereka sendiri terhadap materi pelajaran, menumbuhkan peserta didik dapat berpikir secara sistematis, analitik, dan utuh, serta teratur diimplementasikan dalam bentuk model pembelajaran. Dua model yang dapat digunakan adalah model pembelajaran Learning Cycle dan model pembelajaran Search, Solve, Create, and Share (SSCS).

Model pembelajaran Learning Cycle adalah salah satu pendekatan pembelajaran dengan mengikuti pola tertentu y ang terdiri dari beberapa tahapan pembelajaran. Karakteristik kegiatan belajar pada masing-masing fase benar-benar mencerminkan pengalaman belajar yang dilakukan peserta didik dalam mengkonstruksi dan mengembangkan pemahaman. Model pembelajaran Learning Cycle berorientasi pada pandangan konstruktivisme ini sangat memperhatikan pengalaman dan pengetahuan awal peserta didik serta bertujan untuk meningkatkan pemahaman konsep peserta didik. Lawson (1995: 162) menjelaskan tahapan pada model pembelajaran Learning Cycle yaitu "engagement, exploration, explaination, elaboration, dan evaluation". Tahapan engagement berkaitan pembangkitan minat atau pengetahuan awal tentang konsep yang akan dipelajari. Tahapan exploration berkaitan mengeksplorasi kemampuan peserta didik dalam memahami konsep. Tahapan explaination berupa kemampuan menjelaskan konsep. Tahapan elaboration berupa kemampuan mengkonstuksi pemahaman konsep berdasarkan pengalamannya. Sedangkan pada evaluation adalah penilaian terhadap tingkat pemahaman konsep pesertadidik.

Sedangkan model pembelajaran Search, Solve, Create, and Share (SSCS) Ramson (2010:13) menjelaskan bahwa "model pembelajaran Search, Solve, Create, and Share (SSCS) adalah modal pembelajaran yang mengunakan pendekatan problem solving”. Model ini didisain untuk mengembangkan keterampilan berpikir dan meningkatkan pemahaman terhadap konsep ilmu. Model pembelajaran Search, Solve, Create, and Share (SSCS) melibatkan peserta 
didik dalam menyelidiki sesuatu, membangkitkan minat bertanya serta memecahkan masalah ny ata. Pizzini et al (Chin, 1997; Ramson, 2010; Irwan, 2011) menjelaskan bahwa "terdapat empat tahapan yang terdapat dalam model ini, yaitu tahapan search, tahapan solve, tahapan create, dan tahap an share."

Rumusan masalah yang diajukan adalah: pertama, bagaimanakah pemahaman konsep pada peserta didik y ang menerapkan model pembelajaran Learning Cycle dibandingkan dengan pemahaman konsep pada peserta didik y ang menerapkan model pembelajaran Search, Solve, Create, and Share (SSCS). Kedua, bagaimanakah efektifitas penerapan model pembelajaran Learning Cycle dibandingkan dengan efektifitas penerapan model pembelajaran Search, Solve, Create, and Share (SSCS).

Hipotesis y ang diajukan adalah: pertama, terdapat perbedaan pemahaman konsep pada peserta didik antara yang menerapkan model pembelajaran Learning Cycle dengan pemahaman konsep pada peserta didik antara y ang menerapkan model pembelajaran Search, Solve, Create, and Share (SSCS). Kedua, terdapat perbedaan efektifitas penerapan model pembelajaran Learning Cycle dengan efektifitas penerapan model pembelajaran Search, Solve, Create, and Share (SSCS). Uji hipotesis dengan Wilcoxon Sign Test untuk memperbandingkan nilai pretes dan postes, tujuanny a untuk mengetahui ada tidakny a peningkatan pemahaman konsep setelah perlakuan kedua model pembelajaran. Uji hipotesis lain adalah Two Sample Kolmogorov Smirnov Test, untuk memperbandingkan pretes, postes dan observasi antara kedua model pembelajaran untuk mengetahui ada tidak perbedaan pemahaman konsep dan efektivitas dari kedua pembelajaran.

\section{METODE PENELITIAN}

Metode penelitian yang digunakan adalah metode eksperimen dengan desain kelompok pembanding pretes dan postest (pretest-posttest comparasion group design). Populasi penelitian adalah seluruh peserta didik kelas XI Program IPS di SM A Negeri 1 Cihaurbeuti Kabupaten Ciamis. Sedangkan sampel penelitian adalah kelas XI IPS 2 mendapat perlakuan model pembelajaran Learning Cycle dan kelas XI IPS 4 mendapat perlakuan model pembelajaran model pembelajaran Search, Solve, Create, and Share (SSCS). Instrumen terdiri dari tes pemahaman, LKS dan lembar observasi.

\section{HAS IL DAN PEMBAHAS AN}

Hasil penelitian menunjukkan bahwa pemahaman konsep pada peserta didik mengalami peningkatan setelah perlakuan model pembelajaran Learning Cycle dan model pembelajaran Search, Solve, Create, and Share (SSCS). Untuk lebih jelas dapat dilihat pada Tabel 1.

Tabel 1. Uji z Pretes dan Postes

\begin{tabular}{ccccc}
\hline \multicolumn{5}{c}{ Wilcoxon Signed Rank } \\
\hline Variabel & $\begin{array}{c}\text { Asymp. Sig. } \\
\text { Hitung }\end{array}$ & $\begin{array}{c}\text { Z } \\
\text { (2-tailed)/2 }\end{array}$ & Tabel & Kesimpulan \\
\hline Pretes LC - Postes LC & $-3,254$ & 0,0005 & $-1,645$ & Meningkat secara signifikan \\
\hline Pretes SSCS - Postes SSCS & $-2,789$ & 0,0025 & $-1,645$ & Meningkat secara signifikan \\
\hline
\end{tabular}

Sumber: Hasil penelitian, 2012.

Hasil penelitian juga menunjukkan bahwa nilai pretes dan postes antara model pembelajaran model pembelajaran Learning Cycle dan model pembelajaran Search, Solve, Create, and Share (SSCS) sama/identik. Artiny a tidak terdapat perbedaan pemahaman konsep pada peserta didik yang menerapkan model pembelajaran Learning Cycle dengan yang menerapkan model pembelajaran Search, Solve, Create, and Share (SSCS). Untuk lebih jelas dapat dilihat pada Tabel 2. 
Tabel 2. Perbandingan Pretes dan Postes

\begin{tabular}{lcrl}
\hline \multicolumn{4}{c}{ Two Sample Kolmogorov Smirnov } \\
\hline Variabel & $\alpha$ & $\begin{array}{c}\text { Asymp. Sig. } \\
\text { (2-tailed) }\end{array}$ & Kesimpulan \\
\hline Pretes & 0,437 & 0,991 & Identik \\
\hline Postes & 0,403 & 0,997 & Identik \\
\hline
\end{tabular}

Sumber: Hasil penelitian, 2012.

Hasil penelitian selanjutnya menjelaskan bahwa efektifitas antara model pembelajaran model pembelajaran Learning Cycle dan model pembelajaran Search, Solve, Create, and Share (SSCS) sama/identik. Artinya tidak terdapat perbedaan efektifitas pada peserta didik yang menerapkan model pembelajaran Learning Cycle dengan yang menerapkan model pembelajaran Search, Solve, Create, and Share (SSCS). Untuk lebih jelas dapat dilihat pada Tabel 3.

Tabel 3. Perbandingan Hasil Observasi

\begin{tabular}{cccc}
\hline \multicolumn{4}{c}{ Two Sample Kolmogorov Smirnov } \\
\hline Variabel & $\alpha$ & $\begin{array}{c}\text { Asymp. Sig. } \\
\text { (2-tailed) }\end{array}$ & Kesimpulan \\
\hline Observasi & 0,492 & 0,969 & Identik \\
\hline Sumber: Hasil penelitian, 2012. &
\end{tabular}

Berdasarkan uji hipotesis tersebut dapat disimpulkan bahwa Berdasarkan hal tersebut dapat disimpulkan bahwa pemahaman konsep pada peserta didik antara yang menerapkan model pembelajaran Learning Cycle dengan yang menerapkan model pembelajaran Search, Solve, Create, and Share (SSCS) tidak terdapat perbedaan. Efektifitas penerapan model pembelajaran Learning Cycle dengan model pembelajaran Search, Solve, Create, and Share (SSCS) tidak terdapat perbedaan.

\section{Pemahaman Konsep pada Peserta didik dan Efektifitas Penerapan Model Pembelajaran Learning Cycle}

Pada proses pembelajaran, kegiatan peserta didik mengkonstruksi pengetahuannya lebih terarah. Pembentukan pengetahuan peserta didik dimulai berdasarkan pengetahuan awal atau konsepsi awal. Setelah konsepsi awal terbentuk, peserta didik memulai dengan proses mengeksplorasi konsepsi awal menjadi pengetahuan yang benar. Disebutkan menjadi pengetahuan yang benar karena pada konsepsi awal sering terbentuk konsep kurang tepat, inkonsisten dan bertentangan dengan konsep ilmiah. Perubahan konsep si awal menjadi konsep ilmiah terjadi pada proses verifikasi melalui pengetahuan baru yang diterima yang bersumber dari guru. Guru mengkondisikan pembelajaran yang menimbulkan pertentangan terhadap gagasan peserta didik sehingga akan memberikan esensi dimengerti, dipercay a, dan bermanfaat. Dengan demikian pembentukan pengetahuan peserta didik tidak hany a dari guru tetapi juga dari peserta didik melalui konsepsi awalnya. Setelah pengetahuan atau konsep pengetahuan terbentuk tahapan selanjutny a adalah peserta didik mampu menjelaskan konsep berdasarkan pemahamannya sendiri dan diupayakan untuk dikembangkan pada proses menghubungkan antar konsep atau generalisasi. Meskipun dalam mengkonstruksi pengetahuanny a peserta didik mengalami kesulitan, namun hal tersebut merupakan proses perubahan konseptual yang perlu dilakukan. Perubahan konseptual ini sejalan dengan kaidah konstruktivisme yaitu pengaktifan pengetahuan, membuat asumsi, validasi, mempraktekan dan refleksi pengembangan pengetahuan. Untuk dapat mengoptimalkan proses pembelajaran di kelas perlu diperhatikan kesiapaan guru dan peserta didik dalam menerapkan model pembelajaran ini belum optimal. 
Implikasinya terdapat hambatan dalam mengikuti tahapan-tahapan pembelajaran, misalnya penjelasan y ang berkaitan dengan pola pembelajaran pada setiap tahapan tidak cukup satu kali. Oleh karena itu perlu dilakukan sosialisasi intens terhadap kegiatan pembelajaran yang akan dilakukan.

Berdasarkan nilai LKS pada tahapan yang merupakan gambaran dari tahapan pembelajaran yaitu engagement, exploration, explanation, elaboration dan evaluation menunjukkan pemahaman pesertadidik terhadap soal-soal yag diberikan berkategori jawaban benar dengan penjelasan menunjukkan pemahaman terhadap konsep tetapi ada perny ataan y ang miskonsepsi atau penjelasan belum mengandung semua komponen.

Berdasarkan indikator pemahaman konsep menjelaskan bahwa lebih separuh dari jumlah peserta didik mempunyai kemampuan untuk menafsirkan (interpreting), mengelompokkan (classifying), menyimpulkan (inferring), membandingkan (comparing), dan menjelaskan (explaining). Sedangkan kurang dari separuh peserta didik masih kesulitan dalam meringkas (summarizing) dan mencontohkan (exemplifying).

Identifikasi efektifitas pembelajaran dilakukan melalui pendekatan aktivitas peserta didik dan aktivitas guru. Berdasarkan pengamatan, aktivitas peserta didik masih berada pada tingkatan jarang dilakukan, kadang-kadang, dan sering dilakukan. Persentase aktivitas peserta bervariatif berdasarkan jumlah persentase. Terjadi peningkatan persentase aktivitas peserta didik dari pertemuan kesatu, kedua dan ketiga, meskipun terdapat penurunan aktivitas peserta didik tetapi penurunan persentase tersebut berdampak pada peningkatan persentase menuju kriteria aktivitas yang lebih baik. Terjadi peningkatan aktivitas peserta didik y ang mendukung efektivitas pembelajaran yang mencerminkan proses pembelajaran dari pertemuan kesatu, kedua dan ketiga mengalami perkembangan ke arah lebih baik. Hal ini terjadi karena pada model pembelajaran Learning Cycle pada setiap tahapan memberi kesempatan lebih kepada peserta didik untuk belajar efektif.

Selain aktivitas peserta didik, aktivitas guru juga diamati untuk mengetahui sejauhmana peran guru dalam pembelajaran. Aktivitas guru y ang mendukung efektifitas pembelajaran serta perkembangan peserta didik seperti memberi arahan dan motivasi, memberikan fasilitas pembelajaran, membantu aspek pribadi (sikap, nilai, dan penyesuaian diri) baik pada pertemuan kesatu, kedua, dan ketiga sering dilakukan. Hal ini menandakan bahwa guru berupanya memberi dorongan kepada peserta didik untuk selalu mengikuti pembelajaran dengan baik. Nilai afeksi dan non kognitif lainnya diperhatikan oleh guru sebagai upaya memberikan pembelajaran lain selain materi yang sedang dipelajari oleh peserta didik. Berdasarkan hal tersebut guru berperan baik dalam proses pembelajaran dan mendukung terhadap efektifitas pembelajaran y ang dilakukan.

\section{Pemahaman Konsep pada Peserta didik dan Efektifitas Penerapan Model Pembelajaran Search, Solve, Create, and Share (SSCS)}

Pada proses pembelajaran model Search, Solve, Create, and Share (SSCS) diawali dengan kegiatan mengembangkan pertanyaan dan menetapkan permasalahan. Mengembangkan pertanyaan dan menetapkan permasalahan merupakan upaya menghubungkan antar konsep. Kegiatan ini memberikan motivasi kepada peserta didik karena peserta didik mengetahui langsung penerapan nyata dari konsep. Tahapan selanjutnya adalah mengkonstruksi pemahaman dalam bentuk menghubungkan antar konsep dalam bentuk pemecahan masalah. Pembuatan skema sebagai hasil dari belajar berfungsi sebagai evaluasi proses berpikir peserta didik. Pada skema tergambarkan pola pikir peserta didik dalam proses menetapkan masalah, merumuskan masalah, dan memecahkan masalah. Kegiatan akhir dari pembelajaran adalah penyampaian ide dan gagasan peserta didik dari hasil dari proses pembelajaran sebelumnya y aitu penjelasan dari skema y ang telah dibuat kemudian disampaikan kep ada peserta didik lain. Penyampain gagasan merupakan bentuk penjelasan dari skema yang dibuat oleh masingmasing peserta didik secara tulisan dan lisan. Peny ampaian gagasan peserta didik diupayakan dalam bentuk lisan dengan cara peserta didik menjelaskan gagasannya di depan teman 
sekelasnya. Dengan pertimbangan efektifitas waktu, hanya sebagian peserta didik yang menyampaikan gagasan di depan teman kelasnya. Peserta didik lainnya menyimak dan memberi tanggapan dan kegiatan tanya jawab antar peserta didik.

Berdasarkan nilai LKS y ang merupakan gambaran dari tahapan pembelajaran yaitu search, solve, create, and share menunjukkan pemahaman peserta didik terhadap soal-soal yag diberikan berkategori jawaban benar dengan penjelasan menunjukkan pemahaman terhadap konsep tetapi ada perny ataan y ang miskonsepsi atau belum mengandung semua komponen.

Berdasarkan indikator pemahaman konsep menjelaskan bahwa lebih separuh dari jumlah peserta didik mempunyai kemampuan untuk menafsirkan (interpreting), mengelompokkan (classifying), menyimpulkan (inferring), membandingkan (comparing), dan menjelaskan (explaining). Sedangkan kurang dari separuh peserta didik masih kesulitan dalam mencontohkan (exemplifying).

Identifikasi efektifitas pembelajaran dilakukan melalui pendekatan aktivitas peserta didik dan aktivitas guru. Berdasarkan pengamatan, aktivitas peserta didik masih berada pada tingkatan jarang dilakukan, kadang-kadang, dan sering dilakukan. Persentase aktivitas peserta bervariatif berdasarkan jumlah persentase. Terjadi peningkatan persentase aktivitas peserta didik dari pertemuan kesatu, kedua dan ketiga, meskipun terdapat penurunan aktivitas peserta didik tetapi penurunan persentase tersebut berdampak pada peningkatan persentase menuju kriteria aktivitas y ang lebih baik. Terjadi peningkatan aktivitas peserta didik y ang mendukung efektivitas pembelajaran yang mencerminkan proses pembelajaran dari pertemuan kesatu, kedua dan ketiga mengalami perkembangan ke arah lebih baik. Hal ini terjadi karena pada model pembelajaran Learning Cycle pada setiap tahapan memberi kesempatan lebih kepada peserta didik untuk belajar efektif.

Selain aktivitas peserta didik, aktivitas guru juga diamati untuk mengetahui sejauhmana peran guru dalam pembelajaran. Aktivitas guru yang mendukung efektifitas pembelajaran serta perkembangan peserta didik seperti memberi arahan dan motivasi, memberikan fasilitas pembelajaran, membantu aspek pribadi (sikap, nilai, dan penyesuaian diri) baik pada pertemuan kesatu, kedua, dan ketiga sering dilakukan. Hal ini menandakan bahwa guru berupanya memberi dorongan kepada peserta didik untuk selalu mengikuti pembelajaran dengan baik. Nilai afeksi dan non kognitif lainnya diperhatikan oleh guru sebagai upaya memberikan pembelajaran lain selain materi yang sedang dipelajari oleh peserta didik. Berdasarkan hal tersebut guru berperan baik dalam proses pembelajaran dan mendukung terhadap efektifitas pembelajaran y ang dilakukan.

Diakhir pembahasan didapat kesimpulan dari penerapan model pembelajaran Learning Cycle dan model pembelajaran Search, Solve, Create, and Share (SSCS) adalah: pertama, pada proses pembelajaran kegiatan peserta didik mengkonstruksi pengetahuannya lebih terarah. Kedua, perubahan konseptual pada proses pembelajaran sejalan dengan kaidah konstruktivisme yaitu pengaktifan pengetahuan, membuat asumsi, validasi, mempraktekan dan refleksi pengembangan pengetahuan. Ketiga, pada proses menetapkan masalah, merumuskan masalah, dan memecahkan masalah merupakan upaya mengkonstruksi pemahaman dan generalisasi konsep yang dapat memotivasi peserta didik untuk aktif belajar di kelas. Keempat, penekanan pada kegiatan tanya jawab, penyampaian ide dan gagasan baik tulisan maupun lisan akan mengoptimalkan proses pembentukan pemahaman. Kelima, kesiapan guru dan peserta didik ditingkatkan dengan sosialisasi intens terhadap tahapan-tahapan kegiatan pembelajaran yang akan dilakukan. Keenam, miskonsepsi dan tidak tahu konsep terjadi karena pengetahuan peserta didik bersifat situasional artinya jika dialihkan pada permasalahan lain y ang sama bentuknya dengan permasalahan sebelumnya maka interpretasi permasalahan akan berbeda sehingga ketika dihadapkan pada permasalahan baru atau ditugaskan untuk memberi contoh yang berbeda akan mengalami kesulitan. Selain itu juga dipengaruhi oleh kompleksitas materi. Hal ini berpengaruh terhadap kesulitan penguasaan indikator mencontohkan (examplifying) pada indikator pemahaman konsep oleh peserta didik. Upaya yang dilakukan adalah dengan 
pemberian permasalahan dan contoh yang beragam sehingga memperkay a pengetahuan peserta didik.

\section{S IMPULAN}

Simpulan dari penelitian ini adalah pemahaman konsep pada peserta didik dengan penerapan model pembelajaran Learning Cycle dan Search, Solve, Create, and Share (SSCS) mengalami peningkatan setelah perlakuan. Sebagian besar indikator pemahaman konsep telah dikuasai oleh peserta didik. Indikator yang belum optimal dikuasai adalah kemampuan mencontohkan (exemplifying). Efektifitas penerapan model pembelajaran Learning Cycle dan Search, Solve, Create, and Share (SSCS) dapat disimpulkan: pertama, terjadi peningkatan aktivitas peserta didik y ang mendukung efektivitas pembelajaran y ang mencerminkan proses pembelajaran dari pertemuan kesatu, kedua dan ketiga mengalami perkembangan ke arah lebih baik. Kedua, guru berupany a memberi dorongan kepada peserta didik untuk selalu mengikuti pembelajaran dengan baik.

Rekomendasi dari penelitian ini adalah model pembelajaran Learning Cycle dan Search, Solve, Create, and Share (SSCS) dapat digunakan sebagai salah satu model pembelajaran untuk meningkatkan pemahaman konsep pada pembelajaran Geografi di SMA. Pola belajar konsep difokuskan pada proses pembelajaran berupa mencontohkan (exemplifying) karena berdasarkan penelitian ini indikator pemahaman konsep berupa kemampuan mencontohkan (exemplifying) belum optimal dikuasai. Kemampuan diskriminasi serta kemampaun untuk membedakan contoh dan noncontoh perlu ditingkatkan. Peserta didik masih mengalami keterlambatan dalam memahami konsep serta masih terdapat peserta didik yang mengalami miskonsepsi. Oleh karena itu, proses pembelajaran diharapkan sesuai dengan perkembangan pengetahuan peserta didik dan konsepsiawal peserta didik.

\section{DAFTAR PUS TAKA}

Anderson dan Krathwohl. (2001). A Taxonomy for Learning, Teaching, and Assessing: A Revision of Bloom's Taxonomy of Educational Objectives. New York: Addison Wesley Longman Inc.

Chin, C. (1997). Promoting Higher Cognitive Learning in Science Through a Problem Solving Approach. National Institute of Educational (Singapore). Tersedia di:http://repository.nie.edu.sg/sjpui/bitstream/10497/3767/REACT-1997-1-7.p. [24 September 2011].

Dahar, R. W. (2006). Teori-teori Belajar dan Pembelajaran. Jakarta: Erlangga.

Hamalik, O. (2001). Perencanaan Pengajaran Berdasarkan Pendekatan Sistem. Jakarta: Bumi Aksara.

Irwan. (2011). "Pengaruh Pendekatan Problem Posing Model Search, Solve, Create and Share (SSCS) dalam Upaya Meningkatkan Kemampuan Penalaran Matematis Mahasiswa Matematika (Suatu Kajian Eksperimen pada Jurusan Matematika FMIPA Universitas Negeri Padang)". Jurnal Penelitian Pendidikan. Vol. 12 No. 1. Tersedia di:http://jurnal.upi.edu/file/irwan.pdf. [24 September 2011].

Lawson, E. A. (1995). Science Teaching and The Development of Thinking. Belmont, California: Wadsworth Publishing Company.

Ramson. (2010). Model Pembelajaran Search, Solve, Create and Share (SSCS) untuk Meningkatkan Pemahaman Konsep dan Keterampilan Berpikir Krits Siswa SMP Pada Topik Cahaya. Tesis SPs UPI, Bandung: Tidak diterbitkan. 